\title{
Electromechanical Aspects of an Experimental Hybrid
}

\section{Vehicle}

Silvano R. Rossi ${ }^{1,3}$, Roberto J. de la Vega ${ }^{1}$, Roberto C. Leegstra ${ }^{1}$, Guillermo A. Santillán ${ }^{1}$, Patricia M. Ciancio ${ }^{2,3}$, Marcelo A. Spina ${ }^{1}$, María H. Peralta ${ }^{2,3}$, and Leonel O. Pico ${ }^{2,3}$

1. Department of Electromechanical Engineering, Faculty of Engineering, UNCPBA (National University of Central Buenos Aires), Olavarría B7400JWI, Argentina

2. Department of Civil Engineering, Faculty of Engineering, UNCPBA (National University of Central Buenos Aires), Olavarría B7400JWI, Argentina

3. CIFICEN-CONICET, Argentina

\begin{abstract}
The design and construction of an experimental solar hybrid vehicle based on the combination of photovoltaic solar energy as the main source of electricity and electric power supplied by a generator activated by the driver's pedaling is introduced. The vehicle has a battery to store the energy provided by both systems. The development was motivated by a Latin American solar car race through the Atacama Desert in Chile and the initiative to promote the use of clean energy for transport. A general description of the vehicle, its energetic aspects and experimental results are presented.
\end{abstract}

Key words: Clean energy, solar energy, solar hybrid vehicle, zero emission.

\section{Introduction}

The use of alternative, renewable and clean energies and their sustainable implementation are today a pressing necessity. In particular, the transport sector is one of the main sources of greenhouse gas emissions and air pollution [1]. Alternatives based on the use of clean energies and zero emission are worldwide required to replace vehicles powered by internal combustion engines run with fossil fuel, where carbon dioxide, among others, contributes directly to the greenhouse effect [2].

Controversial and exemplifying policies have been applied in different countries, e.g. the California ZEV (zero emission vehicle), adopted in 1990, establishes that $2 \%$ of vehicles sold until 2003 had to be zero-emission [3].

Currently, an important growth of proposals for scientific and technological development of EV

Corresponding author: Silvano R. Rossi, Ph.D., assistant professor, research fields: electromechanical engineering, and instrumentation. E-mail: srossi@fio.unicen.edu.ar. (electric vehicles), HEV (hybrid electric vehicles) and $\mathrm{ZEV}$ has been observed. In the case of an electric vehicle, the movement occurs by traction of one or more electric motors powered by an external source or from electrical energy accumulating means. On the other hand, a HEV combines an internal combustion engine and an electric machine in order to achieve better performance and fuel economy [4-6].

According to Ref. [7], the automobile industry interpreted the ZEV as an electric vehicle powered by battery, which brought about the development of high-efficiency batteries, such as lithium-ion and vanadium redox flow [8]. This major breakthrough in battery technology, together with the importance of solar energy as a source of renewable energy and the development of solar photovoltaic modules boosted the development of hybrid electric vehicles [9]. A solar zero-emission vehicle is powered by solar panels composed of photovoltaic modules, with battery energy storage, while the traction is provided by an electric motor [10]. According to Ref. [11], the 
potential future market for EVs is higher than that of hybrid and classical internal combustion engines.

This work was motivated by this fact and the challenge of linking scientific and technological knowledge to the global interests of a sustainable planet by promoting the use of renewable and clean energy. The design and construction of an experimental solar vehicle that combines photovoltaic solar energy as the main source of electricity and electric power supplied by a generator activated by a driver's pedaling is presented. Besides, the vehicle consists of a battery to store the energy provided by both systems.

From the point of view of the application of alternative energies, the goal of the project intends to achieve the lowest possible energy consumption to move the vehicle, employing a lightweight, stable, low cost, and zero emission structure. From the point of view of institutional and interdisciplinary work, the aim is to enable the participation of the vehicle in the competition "The Solar Route" to be held in Chile in its successive editions, where Latin American countries can show progress in vehicles running on photovoltaic solar energy. The vehicle called "Pampa Solar" participated in the first and second edition of "The Solar Route" in the Atacama Desert [12], awarded with a prize to the most efficient use of solar energy.

\section{Mechanical Aspects of the Vehicle}

The solar energy utilization and its application in electric traction for vehicle movement needs a special analysis of fundamental points such as: (a) energetic supplies, (b) costs and efficiency of solar panels, (c) how to maximize solar radiation and (d) energy management and control [13]. All the points above mentioned were considered for both the mechanic and electric design in building the Pampa Solar.

The solar vehicle was built from a structure resting on three wheels, in an inverted tricycle form, for a single driver in a decumbent position. The development included, on the one hand, the project and design phase of the vehicle's frame, focusing on an optimized structural work for small power consumption. On the other hand, it includes the project, design and calculation of the structure of the plate where the solar panels are distributed.

The first phase of the project involved the consideration of different materials, types of joints, support forms, using analytical models to arrive at the solution of the problem. Fig. 1 shows the model for the structural frame analysis, where: (1) main resistant section, (2) support section for the driver's seat, (3) damper system, (4) two angled arms to support the wheels, (5) support rod of a telescopic regulation system for the bottom bracket adjustment, (6) rear fork, to place the electric motor and (7) link between the main frame section and the rear fork.

During the second phase of the project, the structure of the plate located below the solar panels and the support structure that links that plate to the main frame were designed and calculated. Fig. 2 shows the analysis model used at this instance.

In both cases, the structural modeling was performed using commercial software that employs the FEM (finite element method).

For the chassis and the support structure of the screen, linear elements of two nodes were used; and for the screen, a combination of linear elements of two nodes and flat elements of four nodes were employed.

The flat screen is formed by a surface plate made of embedded fiber glass in a polymeric resin which rests

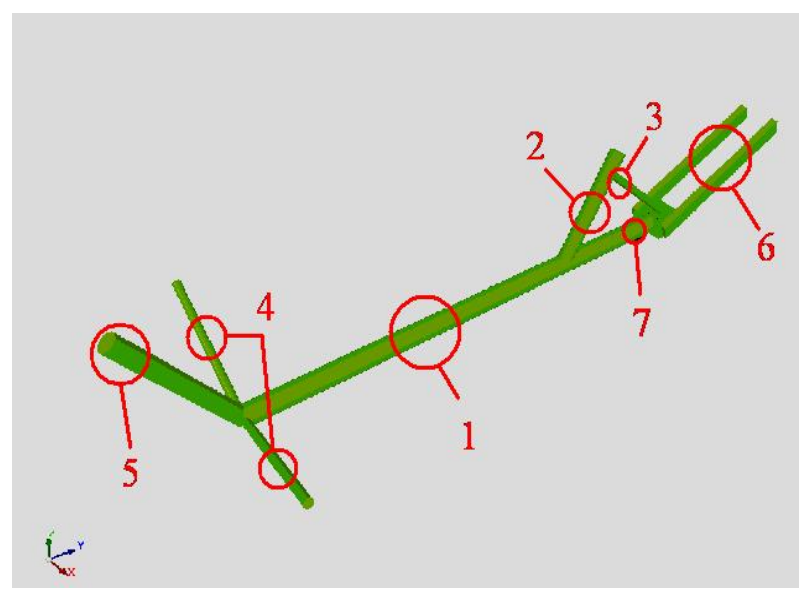

Fig. 1 Structural model for the first phase of the analysis. 


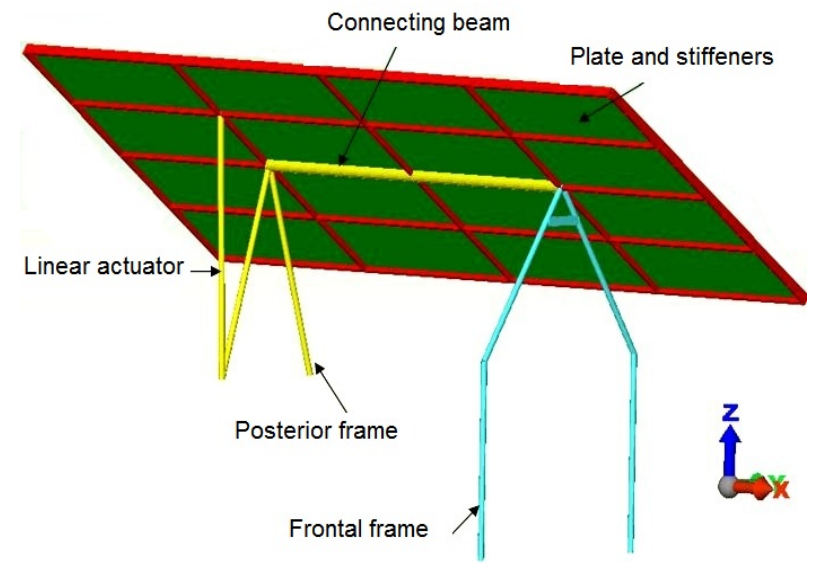

Fig. 2 Structural model for the second phase of the analysis.

on a grid formed by 6063 T6 aluminum alloy pipes. This framework serves as support to the plate reinforced with glass fiber and confers rigidity to its plane.

The whole structure was impregnated with resin in order to obtain a supportive bond among the parts.

The flat plate has a rotary motion over the stiffening bar which allows a rotation of $\pm 35^{\circ}$. From the control panel and depending on the energy requirements, the driver can move the screen with a linear actuator that is part of the mobile solar tracker system.

The mechanical properties of the employed materials are shown in Table 1.

Fig. 3 shows the first prototype of the vehicle "Pampa Solar". The first tests were performed with this mobile.

\section{Electric Part}

The high efficiency electric drive is built into the rear wheel with a brushless, permanent magnet synchronous three phase electric motor, Kelly ${ }^{\circledR}$ model
KEB 48 V-2 kW (Fig. 3), which reaches its best efficiency at a speed of $626 \mathrm{rpm}$ [14].

The designed vehicle uses three different sources of electric energy: (a) photovoltaic solar panels, (b) pedalling driven generator, and (c) batteries. Fig. 4 represents the vehicle's power system block diagram.

The photovoltaic solar energy is collected by solar panels that feed the battery through the MPPT (maximum power point tracker) module of the power-voltage characteristic, operating in reducing voltage mode (buck).

This module is an experimental prototype built in our laboratory. It was used at the competition and it is currently in the final phase of implementation.

Highest possible energy could be obtained from the radiation depending on the angle of incidence. The system is further comprised of the electric motor and the speed and regenerative breaking control module, which allow the recovery of energy during deceleration and braking. Based on the variables measured and displayed, the vehicle' driver stays in a decumbent position to operate a pedal mechanism at the front so as to activate a $180 \mathrm{~W}$, brushless synchronous three phase permanent magnet generator. This is a complementary energy source and depends on the physical capabilities of the driver. An AC/DC rectifier conversion for the AC generator output is necessary in order to supply a suitable continuous voltage level to the battery.

The battery is the storage system of the electrical energy provided by the solar panels and also the energy supply when the motor needs a higher power than the generated (solar and pedals). Prior to battery input, there is a commercial smart charge and discharge

Table 1 Characteristics of the materials.

\begin{tabular}{|c|c|c|c|c|}
\hline Part & Material & $\begin{array}{l}\text { Density } \\
\rho\left(\mathrm{kg} / \mathrm{m}^{3}\right)\end{array}$ & $\begin{array}{l}\text { Elasticity modulus } \\
E\left(\mathrm{~N} / \mathrm{m}^{2}\right)\end{array}$ & $\begin{array}{l}\text { Poisson's } \\
\text { ratio } \\
v\end{array}$ \\
\hline $\begin{array}{l}\text { Main, posterior and } \\
\text { frontal frames }\end{array}$ & Steel & 7,855 & $2 \times 10^{11}$ & 0.29 \\
\hline Stiffening bars & Aluminum alloy & 2,700 & $6.89 \times 10^{10}$ & 0.33 \\
\hline Plate & $\begin{array}{l}\text { Polymeric matrix } \\
\text { reinforced with glass fiber }\end{array}$ & 2,320 & $3.6 \times 10^{10}$ & 0.23 \\
\hline
\end{tabular}




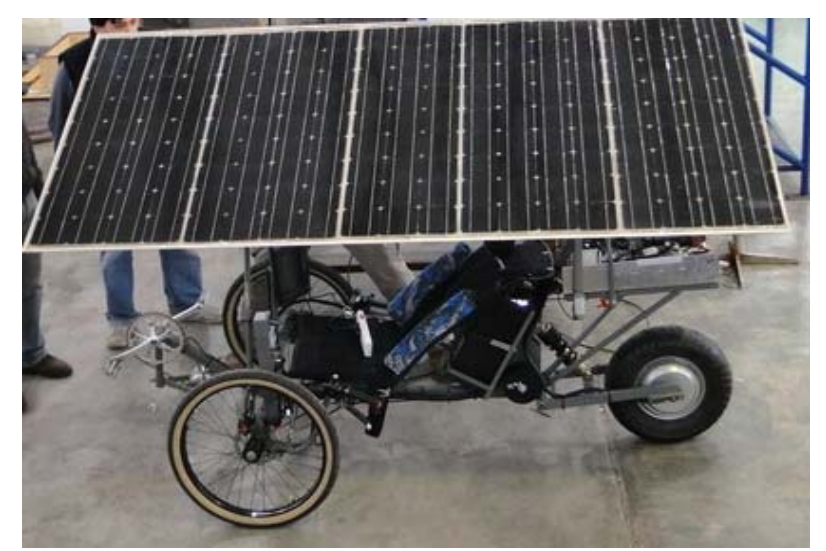

Fig. 3 The "Pampa Solar" prepared for the first test.

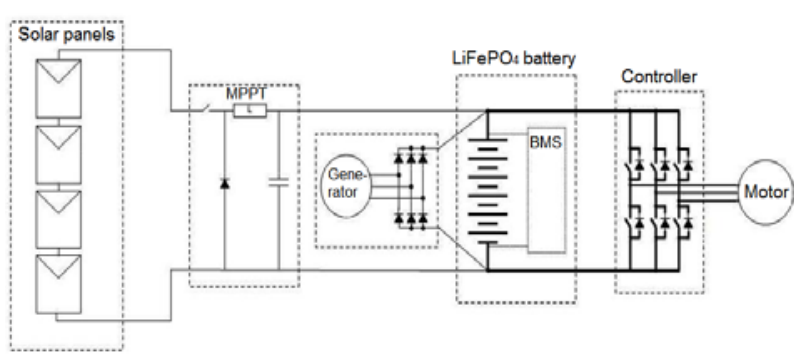

Fig. 4 Simplificated vehicle's power system.

system, called BMS (battery management system) for the $\mathrm{LiFePO}_{4}$ battery technology, which monitors the voltage of each cell, protecting them against overload and unbalanced charge level, thus ensuring the capacity of the assembly at different temperatures during its lifespan.

The vehicle also has a rear compartment for electronics and laptop housing. It has a system of physical variable measurement and data acquisition with PC interface for portable notebook. The evolution of the measured variables can be seen on a compact VGA screen. The battery is placed behind the driver's seat. From a small front panel, the linear actuator for the sunroof can be operated by the driver.

The signal conditioning modules for different physical variable measurement include: photovoltaic and generator voltage and current output, traction energy consumption, battery temperature and voltage, motor current, and GPS signal adaptors.

\section{Energetic Contributions}

Imposed by the competition rules, the sunroof flat area has a $1.2 \times 2.4 \mathrm{~m}^{2}$ rectangular shape. The array is formed by 171 monocrystalline solar cells, distributed in 5 solar panels, 4 of them with 36 cells each, and the remaining with 27. A series of 4 panels was implemented for the $48 \mathrm{~V}$ required system, with the option of adding the fifth, if necessary. In this way, with the considered area, $445 \mathrm{~W}$ of peak power can be obtained.

The solar cells are of $125 \times 125 \mathrm{~mm}^{2}$, with an efficiency of $18 \%$ specified for a $1 \mathrm{~kW} / \mathrm{m}^{2}$ at $25{ }^{\circ} \mathrm{C}$. The solar cells were fully interconnected and encapsulated at the Engineering Faculty.

The encapsulation process is the result of research on different industrial resins, with excellent results in transmission, weight and flexibility with the styrene based polymer use. On the different contrast tests done with a calibrated solar radiation pyranometer pattern, satisfactory results were achieved on efficiency (17\%), weight (10 kg assembly of $3 \mathrm{~m}^{2}$ ), flexibility and final cost, representing one third of commercial module value.

There is an additional energy contribution given by a three phase generator activated by the driver's pedaling. From the physical capabilities of the driver's point of view, it is important to consider that in the case of a conventional bicycle, the leg muscles are used to perform a cyclic movement at a variable speed that can reach $80 \mathrm{rpm}$. In this sense, the literature consulted allows us to analyze some values of power that a person can provide without suffering fatigue or physical damage [15, 16]. Although factors that influence, such as temperature, altitude, pressure and humidity, can vary, an average person can work several hours without fatigue and quickly recover, generating a power of about $70 \mathrm{~W}$. The mentioned energy is used to provide, at a normal rhythm, a power in a range of 30 to $70 \mathrm{~W}$, depending on the charge of the batteries. The main characteristics and the elements employed for this system are: (a) a 54 tooth sprocket, (b) a 12 tooth sprocket, (c) a chain, (d) pedals, (e) a generator, and (f) an AC/DC rectifier. 
The proper battery sizing establishes the autonomy of the vehicle [17]. The main objective is to find a proper relationship of weight, volume, energy density, life cycle, cost and environmental impact.

A study and comprehensive analysis of alternatives and technologies in the market to determine an appropriate balance among the above parameters were performed. After a series of tests and comparative analysis among different types of energy storage batteries [18-21] a lithium iron-phosphate $\left(\mathrm{LiFePO}_{4}\right)$ was selected, made up of 16 arrays in series, each one with seven cells in parallel, obtaining a 48 V-40 Ah battery pack.

The choice goes to the $\mathrm{LiFePO}_{4}$ technology due to its relevant characteristics for use in electric vehicles rather than classical lead acid batteries. The most important features are: average cell voltage 3.2-3.3 V, gravimetric energy density of about $100 \mathrm{Wh} / \mathrm{kg}$, volumetric power density of about $200 \mathrm{Wh} / \mathrm{l}$, temperature range operation from -20 to $70{ }^{\circ} \mathrm{C}$ and a high life cycle close to 2,000 cycles (@ 80\% DOD), [18]. It also represents about a half of the volume and one-third the weight of lead-acid batteries. Another key aspect of this technology is that it has a low environmental impact and it is guaranteed by the RoHS directive.

\section{Final Version of the Vehicle}

The photograph in Fig. 5 shows the "Pampa Solar" hybrid vehicle in its final version prepared for the Solar Challenge across the Atacama Desert, Chile. Table 2 shows the main vehicle's technical specifications.

\section{Experimental Results}

The race took place over three days, in the Atacama Desert, Chile, covering three main sections: (1) Humberstone-Antofagasta (453.8 $\mathrm{km})$, Antofagasta-Calama (214.5 km) and (3) Calama-Iquique (388.3 km).

The total energy consumption during the competition was 7,394 Wh. The energy balance was comprised by

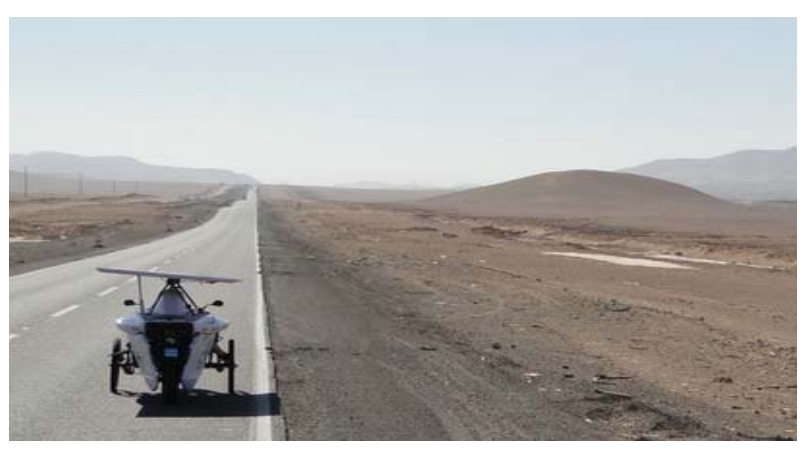

Fig. 5 The vehicle during the solar race.

Table 2 Main technical specifications and characteristics.

\begin{tabular}{|l|l|}
\hline Part/variable & Characteristic/specification \\
\hline Photovoltaic solar cells & Monocrystalline \\
\hline Solar roof & $\begin{array}{l}\text { 4 panels comprised by 36 cells } \\
-1 \text { panel comprised by 27 cells }\end{array}$ \\
\hline $\begin{array}{l}\text { Maximum power of the } \\
\text { panel (solar roof) }\end{array}$ & $445 \mathrm{~W}$ \\
\hline Battery & $48 \mathrm{~V} / 40 \mathrm{Ah}$-LiFePO4 Technology \\
\hline MPPT & Designed prototype_buck mode \\
\hline Electric motor & $\begin{array}{l}48 \mathrm{~V}-2 \mathrm{~kW} \text {-brushless, } \\
\text { permanent magnet }\end{array}$ \\
\hline Electric generator & $48 \mathrm{~V}-240 \mathrm{~W}$ \\
\hline Weight & $165,5 \mathrm{~kg}$ \\
\hline Maximum speed & $55 \mathrm{~km} / \mathrm{h}$ \\
\hline Autonomy & $\begin{array}{l}150 \mathrm{~km} \\
\text { (usual solar condition—@ } 9 \mathrm{~km} / \mathrm{h} \text { ) }\end{array}$ \\
\hline Vehicle fairing & Fiber glass \\
\hline
\end{tabular}

the total energetic support of each power source, considering (a) energy provided by the battery: 3,533 Wh (47\%), (b) solar energy 3,153 Wh (43\%), and (c) energy provided by the electric generator: $708 \mathrm{Wh}$ $(10 \%)$.

This balance was quite different depending on the topology of the route. As an example, during the third day of the race in the main section (Calama-Iquique), due to the negative average slope value, energy was recovered by the regenerative braking system of the vehicle in addition with the other three energy sources. This fact may be seen by analyzing the data presented in Table 3, which shows two subsections of the (Calama-Iquique) section, considering the connection between them. A total of 70\% solar energy, $9 \%$ pedal generator electric energy and $21 \%$ battery supplied energy was used. It could be observed the negative value corresponding to the first section, and the stretch 
Table 3 Energetic balance, corresponding to third day of competition.

\begin{tabular}{lllll}
\hline $\begin{array}{l}\text { Total energy } \\
\text { (Wh) }\end{array}$ & $\begin{array}{l}\text { First } \\
\text { section }\end{array}$ & $\begin{array}{l}\text { Connection } \\
\text { between } \\
\text { sections }\end{array}$ & $\begin{array}{l}\text { Second } \\
\text { section }\end{array}$ & Total \\
\hline Consumption & 388 & 87 & 2,002 & 2,477 \\
Solar & 455 & 486 & 798 & $1,739(70 \%)$ \\
Battery & -199 & -399 & 1,120 & $522(21 \%)$ \\
Generator & 132 & 0 & 84 & $216(9 \%)$ \\
\hline
\end{tabular}

that connects both the sections, respectively, due to steep slopes downhill, that is, the battery accumulates energy in these cases. In the second section, in contrast, there was a substantial battery contribution, because of the route characteristics.

Regarding the power provided by the driver pedaling generator during the competition, a $242 \mathrm{~W}$ peak power was extracted, which is more than the double that a rider can deliver for a long time without fatigue. Therefore, considering the driver's position and that no signs of fatigue appeared, the results were highly promising.

Thus, the results of generating electrical energy using a brushless electric machine attached to a kinematic chain and the pilot's recumbent position were validated.

The maximum values measured throughout the competition were: electric motor power $(2,203 \mathrm{~W})$, solar power (286 W), generator current (5,1 A), and speed $(51 \mathrm{~km} / \mathrm{h})$.

Fig. 6 depicts the evolution of the motor current, panel current and battery voltage as function of time. As it may be seen, the electric motor current takes negative values due to energy recouping during braking and decelerations. In these situations the battery voltage increases its value, while the panel current is practically constant.

After the solar car race, the "Pampa Solar" won the "Solar Energy Use Award" as recognition to the vehicle that used as much of that energy during the competition in the category "The Solar Route".

\section{Conclusions}

The design and construction of an experimental solar

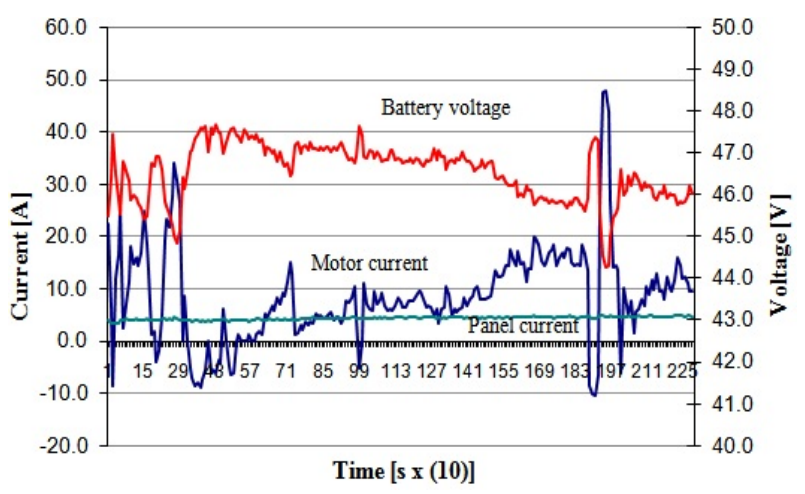

Fig. 6 Motor current, panel current and battery voltage as function of time.

hybrid vehicle was possible from a multidisciplinary project. The first solar car race in Latin America allowed us to validate the vehicle's performance results. The behavior of the mechanical, electric and vehicle electronics, as well as the energetic system, especially the photovoltaic panel system, showed great reliability.

The different phases of research led to the use of lithium-iron phosphate batteries due to their relevant features for electric vehicles, considering efficiency and lower environmental impact compared to traditional lead acid batteries. It was possible to obtain a very satisfying result in the use of solar panels and also an attractive cost compared to commercial modules.

As a result of research on different industrial resins for solar cells integration and encapsulation process, styrene polymer encapsulate was used.

The next challenges aim at developing a new version of the vehicle by removing the electric generator and analyzing its possible applications to transportation.

\section{Acknowledgments}

This work was supported in part by Faculty of Engineering-UNCPBA, Buenos Aires Province Scientific Research Commission (CIC), and the Olavarría City Municipality. Likewise, a special acknowledgment is also extended to companies and institutions that demonstrated their commitment with this project.

\section{References}

[1] Thomas, C. E. S. 2009. "Transportation Options in a 
Carbon-Constrained World: Hybrids, Plug-in Hybrids, Biofuels, Fuel Cell Electric Vehicles, and Battery Electric Vehicles.” Intl. Journal of Hydrogen Energy 34: 9279-96.

[2] Situ, L. 2009. "Electric Vehicle Development: The Past, Present \& Future.” In Proc. Intl. Conf. on Power Electronic Systems and Applications, 1-3.

[3] Collantes, G., and Sperling, D. 2008. "The Origin of California's Zero Emission Vehicle Mandate.” Transportation Research Part A: Policy and Practice 42 (10): 1302-13.

[4] Momoh, O. D., and Omoigui, M. O. 2009. "An Overview of Hybrid Electric Vehicle Technology.” In Proc. IEEE Vehicle Power and Propulsion Conference, 1286-92.

[5] Magneto, G., and Van Mierlo, J. 2000. Electric and Electric Hybrid Vehicle Technology: A Survey.” In Proc. IEE Seminar on Electric, Hybrid and Fuel Cell Vehicles, 1-11.

[6] Arsie, I., Di Martino, R., Rizzo, G., and Sorrentino, M. 2008. "Energy Management for a Hybrid Solar Vehicle with Series Structure." In Proc. of the $17^{\text {th }}$ World Congress-The Int. Federation of Automatic Control, 3362-67.

[7] Cairns, E. J. 1992. “A New Mandate for Energy Conversion: Zero Emission (Electric) Vehicles.” In Proc. IEEE $35^{\text {th }}$ Intl. Power Sources Symposium, 310-3.

[8] Singh, B. R., and Singh, O. 2010. "21st Century challenges of clean energy and global warming-can energy storage systems meet these issues?” In Proc. Thermal Issues in Emerging Technologies, 323-9.

[9] Giannouli, M., and Yianoulis, P. 2012. "Study on the Incorporation of Photovoltaic Systems as an Auxiliary Power Source for Hybrid and Electric Vehicles.” Solar Energy 86: 441-51.

[10] Connors, J. 2007. “On the Subject of Solar Vehicles and the Benefits of the Technology." In Proc. ICCEP'07, 700-5.

[11] Shin, J., Hong, J., Jeong, G., and Lee, J. 2012. "Impact of Electric Vehicles on Existing Car Usage: A Mixed Multiple Discrete-Continuous Extreme Value Model Approach.” Transportation Research Part D: Transport and Environment 17 (2): 138-44.

[12] http:// www.atacamasolarchallenge.com.

[13] Rizzo, G., Arsie, I., and Sorrentino, M. 2010. "Solar Energy for Cars: Perspectives, Opportunities and Problems.” In Proceedings of GTAA Meeting, 1-6.

[14] http://www.kellycontrols.com.

[15] Whitt, F. R., and Wilson, D. G. 1982. Bicycling Science. 2nd edition. USA: The MIT Press.

[16] Wilson, S. S. 1973. "Bicycle Technology.” Scientific American 2287 (3): 81-91.

[17] Affanni, A., Bellini, A., Franceschini, G., Guglielmi, P., and Tassoni, C. 2005. "Battery Choice and Management for New-Generation Electric Vehicles.” IEEE Transactions on Industrial Electronics 52 (5): 1343-9.

[18] Kularatna, N. 2011. "Rechargeable Batteries and Their Management.” IEEE Instrumentation and Measurement Magazine 14 (2): 20-33.

[19] Gibson, T. L., and Kelly, N. A. 2010. "Solar Photovoltaic Charging of Lithium-Ion Batteries.” Journal of Power Sources 195: 3928-32.

[20] Jiayuan, W., Zechang, S., and Xuezhe, W. 2009. "Performance and Characteristic Research in $\mathrm{LiFePO}_{4}$ Battery for Electric Vehicle Applications.” In Proc. IEEE Vehicle Power and Propulsion Conf., 1657-61.

[21] Moore, S. W., and Schneider, P. J. 2001. “A Review of Cell Equalization Methods for Lithium-Ion and Lithium-Polymer Battery Systems.” Society of Automotive Engineers, 1-5. 